\title{
PENINGKATAN MOTIVASI BELAJAR MATEMATIKA MELALUI DISCOVERY LEARNING DENGAN APLIKASI GOOGLE SUITE FOR EDUCATION
}

\author{
IMPROVING MATHEMATIC LEARNING MOTIVATIONS THROUGH DISCOVERY \\ LEARNING WITH GOOGLE SUITE FOR EDUCATION
}

\author{
SRI WAHYUNI \\ SMPN 109 Jakarta
}

\begin{abstract}
Received: March 09, 2021

Conventional learning doesn't support students' motivation to learn mathematics during the Revised: September 30, 2021 Covid-19 pandemic. The purpose is to increase motivation learning mathematics through distance Accepted: November 26, 2021 learning with discovery learning-google suite for education. The research was conducted in class VIII of SMP Negeri 109 Jakarta semester 2019-2020 using Classroom Action Research which consists of planning, implementation, observation, reflection. Based on data analysis found: 1) the average motivation to learn mathematics in cycle $1=73.17$ increased to 77.72 in cycle 2, includes: diligent, tenacious, interest, independent, bored on routine tasks, maintains opinions, sure, can solve the problem; 2 ) the average activity increased from cycle $1=83.4 \%$ to $92.6 \%$ in cycle 2 , included: happy solving problems; actively involved; conveying ideas; attending and submitting assignments on time. The conclusion of this research is through discovery learning-google suite for education, it can increase students' learning motivation and activities in distance learning mathematics.
\end{abstract}

\begin{abstract}
Abstrak.
Pembelajaran konvensional kurang mendukung motivasi belajar matematika siswa dimasa pandemi Covid-19. Tujuan penelitian ini untuk meningkatan motivasi belajar matematika melalui penerapan pembelajaran jarak jauh dengan discovery learning-google suite for education. Penelitian dilakukan di kelas VIII SMP Negeri 109 Jakarta semester genap tahun pelajaran 2019-2020 menggunakan Penelitian Tindakan Kelas yang terdiri dari perencanaan, pelaksanaan, pengamatan, refleksi. Berdasarkan analisis data ditemukan: 1) rata-rata motivasi belajar matematika pada siklus 1= 73,17 meningkat menjadi 77,72 pada siklus 2, Peningkatan motivasi siswa tersebut meliputi; tekun dalam menghadapi tugas; ulet dalam menghadapi kesulitan; menunjukkan minat; senang bekerja mandiri; cepat bosan pada tugas-tugas rutin; dapat mempertahankan pendapat; tidak mudah melepas hal yang diyakini; senang mencari dan memecahkan masalah; 2) rata-rata aktivitas meningkat dari siklus1 $=83,4 \%$ menjadi $92,6 \%$ pada siklus 2, peningkatan aktivitas siswa tersebut meliputi: hadir tepat waktu; kumpulkan tugas tepat waktu; senang memecahkan soal; terlibat aktif; menyampaikan ide. Simpulan penelitian ini adalah melalui discovery learning-google suite for education dapat meningkatkan motivasi belajar dan aktivitas siswa pada pembelajaran matematika jarak jauh.
\end{abstract}

\begin{tabular}{ll}
$\begin{array}{l}\text { Keywords: } \\
\text { Kata kunci: }\end{array}$ & $\begin{array}{l}\text { motivation to learn mathematics, distance learning, discovery learning, google suite for education } \\
\text { motivasi belajar matematika, pembelajaran jarak jauh, discovery learning, google suite for } \\
\text { education }\end{array}$ \\
\hline$\left(^{\star}\right.$ Corresponding Author: & sriwahyunisoepadi@gmail.com \\
\hline How to Cite: Wahyuni, S., (2021). Peningkatan Motivasi Belajar Matematika Melalui Discovery Learning Dengan Aplikasi Google \\
Suite For Education. Jurnal Lingkar Mutu Pendidikan, $18(2), 216-226$. https://doi.org/10.54124/jlmp.v18i1.20 \\
\hline
\end{tabular}

\section{PENDAHULUAN}

Motivasi belajar merupakan salah satu faktor penting yang ikut menentukan keberhasilan belajar siswa. Siswa yang memiliki motivasi belajar yang tinggi cenderung untuk terlibat aktif dalam proses pembelajaran, selalu berusaha mencapai apa yang diinginkan walaupun mengalami hambatan dan kesulitan dalam memperolehnya, sehingga menyebabkan tingkat keberhasilan siswa dalam belajar tinggi. Peran guru dalam motivasi belajar siswa adalah menggerakkan, menggugah, mendorong, 
menimbulkan keinginan yang kuat serta menyadarkan siswa untuk belajar secara sungguh-sungguh mengikuti dalam proses belajar mengajar secara sadar dan bertujuan.

Dalam proses pembelajaran motivasi berperan penting untuk mendorong siswa melakukan kegiatan belajar sehingga tujuan belajarnya tercapai. Ciri-ciri motivasi belajar yang ada pada siswa antara lain: tekun menghadapi tugas, ulet menghadapi kesulitan, tidak memerlukan dorongan dari luar, menunjukkan minat terhadap bermacam-macam masalah; lebih senang bekerja mandiri; cepat bosan pada tugas yang rutin; dapat mempertahankan pendapatnya; tidak mudah melepaskan hal yang diyakini itu, senang mencari dan memecahkan masalah soal-soal (Sardiman 2018).

Berdasarkan pendapat pakar motivasi belajar maka dalam penelitian ini yang dimaksud dengan motivasi belajar siswa adalah motivasi yang mendorong seseorang untuk terlibat secara aktif dalam proses belajar sehingga tujuan pembelajaran tercapai yang dapat diukur melalui tekun dalam menghadapi tugas, ulet dalam menghadapi kesulitan, menunjukkan minat belajar; senang bekerja mandiri; memiliki rasa ingin tahu, dapat mempertahankan pendapat; percaya diri; senang memecahkan masalah.

Pembelajaran Jarak Jauh diterapakan di Indonesia karena demi pencegahan penularan Covid-19. Pembelajaran Jarak Jauh atau dikenal dengan distance learning adalah suatu bentuk pembelajaran di mana siswa dan guru terpisah oleh jarak dan waktu. (Wahyuningsih and Makmur 2017). Ada dua macam pembelajaran dari rumah, yaitu belajar dengan penugasan dan belajar jarak jauh/ daring. Belajar dengan penugasan dilakukan dengan cara: pengaturan waktu dan jarak (penjadwalan pengambilan tugas di sekolah dari guru untuk siswa); membuat kotak penugasan di kantor desa/ kelurahan (guru meletakkan tugas-tugas di kantor desa/kelurahan); memanfaatkan jasa pengantaran pos. Pembelajaran berbasis daring yaitu pembelajaran jarak jauh yang memanfaatkan internet dilakukan dengan cara: menggunakan portal pembelajaran online misalnya: portal Dinas Pendidikan; portal Kemenag; portal Rumah Belajar; Ruang Guru; menggunakan portal pembelajaran online mandiri misalnya; google Classroom, Zoom Meeting, Webex, Jitsi, dan lain-lain (Samin 2020).

Berdasarkan uraian para pakar tentang pembelajaran jarak jauh maka dalam penelitian ini yang dimaksud pembelajaran jarak jauh adalah suatu bentuk pembelajaran di mana siswa dan guru terpisah oleh jarak dan waktu dilakukan secara daring atau berbasis internet.

Proses belajar mengajar di SMP Negeri 109 Jakarta dilakukan secara daring atau online. Praktik pembelajaran jarak jauh yang diterapkan tanpa persiapan baik guru maupun siswa mengalami beberapa kendala antara lain minimnya pengetahuan guru tentang pembelajaran jarak jauh, guru hanya menerapkan model pembelajaran secara monoton.

Pengetahuan guru tentang aplikasi yang mendukung pembelajaran jarak jauh hanya menggunakan aplikasi pesan singkat yaitu WhatsApp. Pembelajaran seperti ini menyebabkan kurang interaksi antara siswa dan guru. Guru lebih suka memberi tugas kepada siswa. Materi pelajaran khususnya pelajaran matematika sulit dipahami oleh siswa sehingga menyebabkan motivasi belajar matematika siswa menurun.

Berdasarkan hasil angket siswa terhadap proses pembelajaran jarak jauh, sebelum peneliti menggunakan model pembelajaran discovery learning dengan aplikasi google suite for education menunjukkan bahwa motivasi belajar matematika kelas VIII-6 SMP Negeri 109 Jakarta kategori rendah. Pengisian angket pembelajaran pada pra siklus dilaksanakan pada hari senin, tanggal 20 April 2020 di kelas VIII-6 Jakarta diikuti oleh 30 siswa melalui aplikasi google form. Angket respon siswa terhadap proses pembelajaran jarak jauh berisi 8 butir pernyataan positif menggunakan skala guthman dengan jawaban ya atau tidak. Hasil angket respon siswa terhadap proses pembelajaran jarak jauh menyatakan bahwa terdapat 33,33\% siswa menyatakan terlambat online dengan alasan kesiangan. Terdapat 38,9\% siswa merasa Pembelajaran Jarak Jauh tidak menyenangkan. Terdapat $50 \%$ siswa merasa bahwa materi pelajaran tidak mudah dipahami, terdapat $16 \%$ siswa menganggap aplikasi yang digunakan kurang bermanfaat bagi siswa walaupun sebanyak $75 \%$ siswa menganggap aplikasi yang digunakan mudah. Siswa yang tidak mengikuti pembelajaran jarak jauh cukup tinggi rata-rata antara 5 sampai 9 siswa dari jumlah seluruh siswa di kelas VIII-6 yaitu 36 orang, padahal data sekunder yang diperoleh dari laporan wali kelas dan guru BK kelas VIII-6 SMP Negeri 109 Jakarta bahwa seluruh siswa memiliki gawai/laptop/komputer, jaringan internet lancar, dan tidak bermasalah 
dengan kuota internet. Siswa yang merespon atau terlibat aktif pada proses pembelajaran jarak jauh rata-rata hanya $25 \%$. Siswa yang tekun mengerjakan tugas 33\%.

Untuk mengatasi permasalahan yang telah diuraikan di atas maka peneliti mencoba menerapkan pembelajaran discovery learning-google suite for education pada pembelajaran jarak jauh secara daring.

Discovery learning merupakan model pembelajaran berbasis penyingkapan/penelitian (Permendikbud No.22). Langkah-langkah pembelajaran model pembelajaran discovery learning yang digunakan dalam penelitian ini adalah: pemberian rangsangan (memulai kegiatan belajar dengan mengajukan pertanyaan); identifkasi masalah (memberi kesempatan siswa untuk mengidentifikasi sebanyak mungkin masalah); pengumpulan data (memberi kesempatan siswa mengumpulkan informasi sebanyak-banyaknya); pengolahan data (mengolah data dan informasi yang diperoleh siswa melalui percobaan); pembuktian (melakukan pemeriksaan secara cermat untuk pembuk tian dari hipotesis) dan penarikan kesimpulan (menarik sebuah kesimpulan yang dapat dijadikan prinsip umum dan berlaku semua) (Syah 2010).

Model pembelajaran discovery learning memiliki keunggulan dapat meningkatkan motivasi dan aktivitas belajar siswa. Berdasarkan hasil penelitian Hasibuan, dkk (2021) menunjukkan penerapan model pembelajaran discovery learning pada siswa kelas VIII MTs Nurul Iman Tanjung Morawa dapat meningkatkan motivasi dan hasil belajar matematika. Penelitian yang dilakukan Firdayati (2020) pada siswa SMP Negeri 3 Metro menemukan bahwa melalui discovery learning dengan geogebra dapat meningkatkan motivasi dan aktivitas belajar siswa.

Google suite for education adalah sebuah learning management system bersifat gratis sebagai bentuk community development dari Google. Hampir semua fitur yang ada pada akun google standar juga terdapat pada akun Google suite for education namun memiliki fitur tambahan, misalnya kapasitas penyimpanan (storage) yang tak terbatas. Aplikasi ini meliputi aplikasi web populer Google termasuk Gmail, google drive, google Hangouts, google Kalender, dan google documents, google meet. Dengan mengimplementasikan Google Suite for Education di sekolah maka satuan pendidikan selangkah lebih maju dalam penerapan digitalisasi sekolah (Fathur 2018).

Langkah-langkah penggunaan google-suite for education: menggunakan akung-email; menyimpan dan mengorganisir tugas, dokumen; membuat penjadwalan kelas; berkolaborasi, berbagi masukan dan bekerja sama dengan siswa secara langsung di drive, spreadsheet, dan presentasi; buat formulir, kuis, dan survei mengumpulkan dan menganalisis jawaban dengan bantuan machine learning; papan tulis interaktif dengan Jamboard; Web builder yang mudah digunakan untuk membuat situs, menjadi host kurikulum pelajaran, membangun keterampilan dan memfasilitasi kreativitas siswa; google meet untuk pertemuan antara guru dan siswa secara virtual; google classroom untuk membentuk forum kelas yang mendorong pembelajaran; membuat tugas, berkomunikasi dengan siswa, dan memberi masukan, semuanya jadi satu tempat (Google Edu 2020).

Penggunaan aplikasi Google Suite for Education memiliki beberapa kelebihan. Penelitian yang dilakukan Purnamasari \& Kamal (2021) bahwa penggunaan Google Suite for Education dalam Pembelajaran Jarak Jauh pelajaran matematika pada kelas IX di SMP Negeri 6 Pekalongan menemukan siswa terlibat aktif dalam pembelajaran, aktivitas siswa melebihi target 70\%. Talib dan kawan-kawan (2021) menemukan bahwa pembelajaran matematika berbasis google suite for education dapat meningkatkan kecakapan kolaboratif siswa kelas VI SD YPS Singkole.

Implementasi google suite for education di SD Muhammadiyah 09 Plus pada masa pandemi Covid-19 menemukan kendala bila jaringan internet kurang bagus, namun kendala tersebut dapat diatasi dengan cara: sebelum memulai pembelajaran bila menggunakan fitur google meet dengan mematikan kamera dan mengatur microphone sesuai fungsinya, mencari lokasi dengan jaringan internet yang bagus, koordinasi dengan orang tua untuk mencegah siswa memainkan perangkat yang tidak sesuai dengan fungsinya (Nirmala, Triaswati, and Rahmawan 2020).

Berdasarkan latar belakang masalah yang telah dikemukakan maka rumusan masalah penelitian ini adalah "Bagaimanakah upaya meningkatkan motivasi belajar matematika pada pembelajaran jarak jauh melalui discovery learning-google suite for education siswa kelas VIII-6 di SMP Negeri 109 Jakarta tahun pelajaran 2020-2021?". 
Tujuan penelitian tindakan kelas ini untuk meningkatkan motivasi belajar matematika pada pembelajaran jarak jauh melalui discovery learning-google suite for education siswa kelas VIII-6 di SMP Negeri 109 Jakarta tahun pelajaran 2019-2020.

Manfaat teoritis penelitian tindakan kelas ini adalah memunculkan teori bahwa penggunaan discovery learning-google suite for education dapat meningkatkan motivasi belajar matematika siswa. Penelitian tindakan kelas ini secara praktis dapat bermanfaat bagi siswa adalah dapat meningkatkan aktivitas siswa sehingga suasana pembelajaran jarak jauh menjadi menyenangkan hingga pada akhirnya dapat meningkatkan motivasi belajar matematika. Manfaat penelitian bagi guru adalah meningkatkan kompetensi guru dalam penguasaan aplikasi pendidikan yang menunjang pembelajaran jarak jauh dan meningkatkan kreativitas guru dalam menerapkan model pembelajaran yang bervariasi sehingga suasana pembelajaran jarak jauh menjadi menyenangkan. Manfaat penelitian ini bagi sekolah adalah masukan bagi sekolah sebagai bahan pertimbangan dalam pengambilan kebijakan pengembangan pembelajaran jarak jauh.

\section{METODE PENELITIAN}

Penelitian ini dilaksanakan pada bulan April sampai dengan Juni 2020 di SMP Negeri 109 Jakarta. Subyek penelitian adalah siswa kelas VIII-6 yang berjumlah 36. Metode Penelitian adalah Penelitian Tindakan Kelas (PTK), dilaksanakan dalam siklus yang berulang terdiri dari perencanaan, tindakan, pengamatan dan refleksi (Suhardjono 2009). Data dikumpulkan melalui instrumen kuesioner, observasi, angket pembelajaran, penugasan matematika, dan dokumentasi. Data dianalisis dengan teknik deskriptif menggunakan persentase.

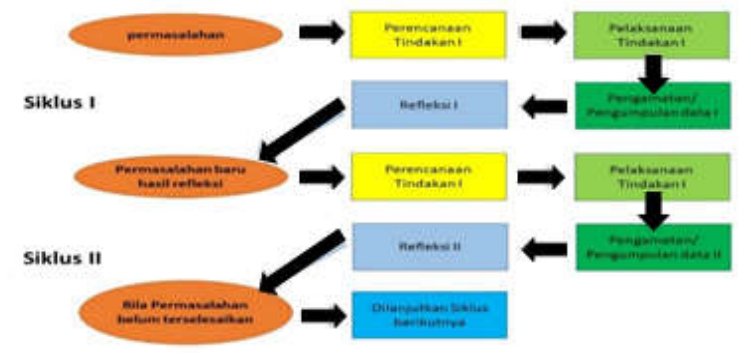

Gambar 1. Bagan Penelitian Tindakan Kelas (Suhardjono 2009)

Berdasarkan Gambar1. Bagan Penelitian Tindakan Kelas maka Penelitian ini terdiri dari 2 siklus dan setiap siklus 3 kali pertemuan dengan langkah-langkah sebagai berikut: 1) Perencanaan melakukan persiapan penelitian yaitu mengkaji masalah, membuat RPP, mencari bahan ajar, menentukan aplikasi yang akan digunakan, menyusun instrumen, membagi kelompok, menyiapkan alat dan bahan; 2) pelaksanaan terdiri dari dua siklus masing-masing siklus 3 kali pertemuan. Setiap pertemuan meliputi kegiatan pendahuluan, inti dan penutup; 3) pengamatan (observasi) dilakukan terhadap aktivitas siswa selama pembelajaran. Kolaborator mengamati dan menyampaikan hasil pengamatan tentang kekurangan dan kelebihan dalam proses belajar mengajar yang dilakukan guru sebagai peneliti; 4) refleksi yaitu menganalisis hasil temuan dan pengkajian ulang hasil observasi dari siklus ke siklus berdasarkan masukan dari kolaborator, untuk pedoman pembelajaran pada pertemuan berikutnya.

\section{HASIL DAN PEMBAHASAN}

Penelitian ini diawali dengan pengamatan terhadap permasalahan yang terjadi pada siswa kelas VIII-6 SMP Negeri 109 Jakarta, sejak diterapkan pembelajaran jarak jauh pada tanggal 16 maret 2020. Sebagian besar motivasi belajar matematika kategori rendah. Siswa yang tidak mengikuti pembelajaran jarak jauh cukup tinggi rata-rata antara 5 sampai 9 siswa dari jumlah seluruh siswa di kelas VIII-6 yaitu 36 orang, padahal data sekunder yang diperoleh dari laporan wali kelas dan guru BK kelas VIII-6 SMP Negeri 109 Jakarta bahwa seluruh siswa memiliki gawai/ laptop/komputer, jaringan internet lancar, dan tidak bermasalah dengan kuota internet. Siswa yang terlibat aktif pada proses pembelajaran jarak jauh rata-rata hanya 25\%. Siswa yang tekun mengerjakan tugas hanya 33\%.

Berdasarkan analisis hasil angket siswa terhadap proses pembelajaran jarak jauh, sebelum peneliti menggunakan model pembelajaran discovery learning dan google suite for education menunjukkan 
bahwa pembelajaran jarak jauh mengalami kendala. Pengisian angket pembelajaran pada pra siklus dilaksanakan pada hari senin, tanggal 20 April 2020 di kelas VIII-6 Jakarta diikuti oleh 30 siswa melalui aplikasi google form. Angket respon siswa terhadap proses pembelajaran jarak jauh berisi 8 butir pernyataan positif menggunakan skala guthman dengan jawaban ya atau tidak. Hasil angket respon siswa terhadap proses pembelajaran jarak jauh menunjukkan: terlambat online dengan alasan kesiangan 33,33\%, pembelajaran jarak jauh tidak menyenangkan 38,9\%, materi pelajaran tidak mudah dipahami $50 \%$, aplikasi yang digunakan kurang bermanfaat $16 \%$ walaupun sebanyak 75\% siswa menganggap aplikasi yang digunakan mudah. Berdasarkan data tersebut maka peneliti terdorong untuk menerapkan model pembelajaran discovery learning dengan menggunakan aplikasi google suite for education yang sesuai dengan karakter kelas VIII-6.

Penelitian dilaksanakan dalam dua siklus dan setiap siklus tiga kali pertemuan. Hasil perencanaan siklus 1 dan siklus 2 adalah sebagai berikut: mengkaji masalah, menyiapkan silabus dan RPP, menyiapkan bahan ajar dan LKS, menyiapkan daftar hadir, menyiapkan lembar angket, lembar pengamatan (observasi) aktivitas siswa maupun guru, kuesioner motivasi belajar matematika, dan lembar penugasan matematika, membagi siswa menjadi 6 kelompok.

Langkah ke dua yaitu pelaksanaan terdiri dari dua siklus masing-masing siklus 3 kali pertemuan. Siklus 1 pertemuan 1 dilaksanan pada hari Senin, tanggal 27 April 2020. Kegiatan pendahuluan meliputi: menyapa siswa, mengecek kesiapan siswa melalui grup WhatsApp, mengingatkan 3M (memakai masker, menjaga jarak, mencuci tangan). membagikan tautan google meet berdoa, menyampaikan kompetensi dasar (KD), memotivasi siswa, menyampaikan tujuan pembelajaran, menyampaikan alat dan bahan, teknik penilaian, memberikan apersepsi/tanya jawab dengan mengingatkan kembali siswa pada materi Statistika: yaitu penyajian data. Pada kegiatan inti guru memberikan rangsangan dengan meminta siswa mengamati materi power point pokok bahasan Statistika yaitu Pemusatan Data (mean, median, modus dan ukuran pemusatan data)". Siswa mengidentifikasi masalah dengan menanyakan hal-hal yang dianggap sulit, diskusi dengan melakukan percobaan. Untuk mengumpulkan data, dan mengemukakan pendapat sebagai pembuktian. Guru mengajak siswa menyanyikan lagu PSBB dengan memutar video sebagai selingan supaya siswa tidak jenuh, mengarahkan dan membimbing siswa untuk menyimpulkan materi pelajaran. Pada kegiatan penutup guru bersama siswa melakukan refleksi pembelajaran, meminta siswa untuk mengerjakan kuis, mengumumkan materi pertemuan yang akan datang yaitu ukuran penyebaran data, memberikan penugasan 5 soal matematika yang dapat dilihat pada google classroom dan menutup pelajaran dengan meminta siswa untuk berdoa dan mengucapkan salam.

Siklus 1 pertemuan 2 dilaksanakan pada hari Kamis, tanggal 30 April 2020. Kegiatan pendahuluan meliputi: menyapa siswa, mengecek kesiapan siswa melalui grub WhatsApp, mengingatkan 3M (memakai masker, menjaga jarak, mencuci tangan). membagikan tautan google meet berdoa, menyampaikan kompetensi dasar (KD), memotivasi siswa, menyampaikan tujuan pembelajaran, menyampaikan alat dan bahan, teknik penilaian, memberikan apersepsi/ tanya jawab dengan mengingatkan kembali siswa pada materi pertemuan sebelumnya yaitu Statistika pemusatan data tentang mean, median, modus. Pada kegiatan inti guru memberikan rangsangan dengan meminta siswa mengamati materi power point pokok bahasan Statistika yaitu Ukuran Penyebaran Data (jangkauan, kuartil, jangkauan interkuartil dan simpangan interkuartil). Siswa mengidentifikasi masalah dengan menanyakan hal-hal yang dianggap sulit, diskusi dengan melakukan percobaan. Untuk mengumpulkan data, dan mengemukakan pendapat sebagai pembuktian Guru mengajak siswa menyanyikan lagu "Corona Jangan Ganggu Aku" dengan memutar video sebagai selingan supaya siswa tidak jenuh, mengarahkan dan membimbing siswa untuk menyimpulkan materi pelajaran. Pada kegiatan penutup guru bersama siswa melakukan refleksi pembelajaran, meminta siswa untuk mengerjakan kuis, mengumumkan materi pertemuan yang akan datang yaitu penilaian harian, memberikan Penugasan 5 soal yang dapat dilihat pada google classroom dan menutup pelajaran dengan meminta siswa untuk berdoa dan mengucapkan salam.

Pada Siklus 1 pertemuan 3 dilaksanakan pada hari Selasa, tanggal 5 Mei 2020, Guru menyapa siswa, kemudian mengecek kesiapan belajar siswa melalui WhatsApp group kelas sebagai media komunikasi dan mengingatkan 3M (memakai masker, menjaga jarak, mencuci tangan), mengajak siswa untuk bergabung di google classroom. setelah siswa berhasil login meminta salah satu siswa untuk memimpin doa "supaya tetap sehat dan lancar belajarnya". Selanjutnya Guru menyampaikan 
tujuan pembelajaran, mmberikan motivasi supaya siswa jujur dalam mengerjakan pengisian kuesioner motivasi belajar matematika, pengisian angket pembelajaran dan penilaian harian, membagikan tautan angket pembelajaran dan tautan kuesioner motivasi belajar matematika, membagikan tautan penilaian harian Matematika kelas VIII-6, memantau jalannya penilaian harian, mengingatkan kepada siswa bahwa waktu tinggal lima menit lagi untuk tidak lupa submit. mengumumkan materi pertemuan yang akan datang yaitu Peluang. Pelajaran diakhiri dengan meminta siswa untuk berdoa dan mengucapkan salam.

Observasi siklus 1, aktivitas siswa yang diamati oleh guru dan kolaborator selama proses pembelajaran dengan menerapkan model pembelajaran discovery learning dan menggunakan aplikasi google suite for education pada siklus 1 terdiri dari: hadir tepat waktu / online pada saat pembelajaran jarak jauh $=82 \%$; tepat waktu mengumpulkan tugas $=81 \%$; senang memecahkan soal $=87 \%$; terlibat aktif/merespon dalam proses pembelajaran jarak jauh $=92 \%$ dan menyampaikan Ide/pendapat= 75\%. Hasil pengamatan melalui lembar observasi siswa tersebut menunjukkan rata-rata keaktifan siswa secara keseluruhan mencapai 83\% telah melampaui target indikator keberhasilan penelitian ini yaitu $75 \%$ menunjukkan bahwa penerapan model pembelajaran discovery learning dan penggunaan aplikasi google suite for education dapat megaktifkan siswa pada proses pembelajaran jarak jauh.

Aktivitas guru yang diamati oleh kolaborator menunjukkan bahwa guru telah melaksanakan langkahlangkah pembelajaran dengan tepat, karena aspek yang di amati oleh kolaborator sebagian besar dinilai sangat baik atau memperoleh skor $=4$. Namun, pada aspek kegiatan tatap muka virtual guru hanya mendapat nilai cukup atau memperoleh skor $=2$ karena pada kegiatan ini guru menghabiskan waktu agak lama yaitu sekitar 20 menit untuk memeriksa kehadiran siswa. Pembelajaran jarak jauh menggunakan aplikasi google suite for education dinilai cukup atau memperoleh skor $=2$ oleh kolaborator karena pada kegiatan ini guru kurang memastikan kesiapan siswa untuk dapat mengakses Google meet salah satu fitur dalam google suite for education saat proses pembelajaran jarak jauh berlangsung sehingga banyak siswa terlambat online.

Berdasarkan data angket siswa menunjukkan bahwa proses pembelajaran jarak jauh dengan menerapkan model pembelajaran discovery learning dan menggunakan aplikasi google suite for education mendapat respon positif oleh siswa, karena rata-rata siswa memberikan respos positif sebesar $87 \%$. Namun masih ada $13 \%$ siswa memberikan respon negatif dengan alasan penggunaan aplikasi google suite for education menghabiskan baterai gawai atau laptop dan terkadang wifi mati sendiri/ koneksi internet kurang bagus sehingga sering keluar dari aplikasi google meet.

Rata-rata skor motivasi belajar matematika termasuk kategori sedang yaitu 73,17 . Hal ini disebabkan penggunaan aplikasi google suite for education pada proses pembelajaran jarak jauh pelajaran matematika materi Statistika dan Peluang merupakan aplikasi yang baru mereka kenal. Penggunaan aplikasi google suite for education dapat mendorong siswa untuk meningkatkan motivasi belajar matematika dalam dirinya. Siswa yang memiliki motivasi belajar matematika kategori tinggi pada siklus 1 adalah 18 orang (50\%), siswa yang memiliki motivasi belajar matematika kategori sedang sebanyak 12 orang (33,3\%), namun pada siklus satu masih ada siswa yang memiliki motivasi belajar matematika kategori rendah yaitu sebanyak 6 orang $(16,7 \%)$. Hal ini disebabkan karena anakanak tersebut kurang terlibat aktif dalam pembelajaran jarak jauh dan hadir terlambat online pada saat pembelajaran jarak jauh.

Refleksi: hasil siklus 1 belum memuaskan, dilihat dari hasil kuesioner motivasi belajar matematika maupun hasil dari observasi di lapangan selama proses pembelajaran jarak jauh. Hasil penelitian siklus 1 ditemukan beberapa masalah antara lain: terdapat 6 siswa $(16,7 \%)$ memiliki motivasi rendah; respon siswa terhadap cara guru mengajar baik; namun ada 3 siswa mengatakan bahasa guru susah di cerna atau penjelasannya kurang terperinci (detil), sehingga materi pelajaran susah di pahami; terdapat 8 siswa belum paham menggunakan aplikasi google suite for education (login ke google meet, login ke google classroom, unggah jawaban ke classwork/google classroom); terdapat 25\% siswa kurang percaya diri dalam menyampaikan pendapat; terdapat $19 \%$ siswa merasa guru kurang membimbing kesulitan siswa; penggunaan aplikasi google suite for education menghabiskan bateray gawai atau laptop dan terkadang wifi mati sendiri/koneksi internet kurang bagus sehingga sering keluar dari aplikasi google meet. Berdasarkan analisis dan refleksi siklus 1, maka perlu perbaikan pada siklus 2. 
Perencanaan pada siklus 2 berlangsung tiga kali pertemuan: Perencanan dilaksanakan sesuai dengan jadwal. Peneliti melakukan perubahan sebagai berikut: bekerjasama dengan wali kelas VIII6, Guru BP, Orang tua untuk mendampingi siswa dalam belajarnya; membuat video pembelajaran yang menarik yang dapat diakses siswa kapan saja dan di mana saja; membuat panduan yang mudah dipahami siswa untuk menggunakan aplikasi google suite for education (login ke google meet, login ke google classroom, unggah jawaban ke classwork/google classroom); bekerjasama dengan wali kelas VIII-6, Guru BP, Orang tua untuk memotivasi siswa agar berani mengemukakan pendapatnya dengan cara persuasif; lebih memperhatikan siswa yang mendapat kesulitan; dan menghimbau kepada siswa untuk sedia power bank/charger laptop/hp saat menggunakan aplikasi google meet, jika koneksi internet mati maka disarankan siswa untuk login kembali ke google meet.

Pelaksanaan siklus 2 pertemuan 1 dilaksanakan pada hari Rabu Tanggal 6 Mei 2020. Kegiatan pendahuluan meliputi: menyapa siswa, mengecek kesiapan siswa melalui grup WhatsApp, mengingatkan $3 \mathrm{M}$ (memakai masker, menjaga jarak, mencuci tangan); membagikan tautan google meet; berdoa; menyampaikan kompetensi dasar (KD); memotivasi siswa; menyampaikan tujuan pembelajaran "Peluang empirik"; menyampaikan alat dan bahan, teknik penilaian, memberikan apersepsi/ tanya jawab dengan mengingatkan kembali siswa pada materi prasyarat "Peluang empirik". yaitu penjumlahan, pengurangan, pada bilangan pecahan.

Pada kegiatan inti guru memberikan rangsangan dengan meminta siswa mengamati materi video "Peluang empirik". Siswa mengidentifikasi masalah dengan menanyakan hal-hal yang dianggap sulit; diskusi dengan melakukan percobaan untuk mengumpulkan data; dan mengemukakan pendapat sebagai pembuktian. Guru mengajak menari "Cuci Tangan Santuy Tik Tok" sebagai selingan supaya siswa tidak jenuh, mengarahkan dan membimbing siswa untuk menyimpulkan materi pelajaran.

Pada kegiatan penutup guru bersama siswa melakukan refleksi pembelajaran, meminta siswa untuk mengerjakan kuis, mengumumkan materi pertemuan yang akan datang yaitu Peluang teoritik, serta perbandingan peluang empirik dan peluang teoritik; memberikan Penugasan 5 soal matematika yang dapat dilihat pada google classroom dan menutup pelajaran dengan meminta siswa untuk berdoa dan mengucapkan salam.

Siklus 2 pertemuan 2 pada hari Selasa, tanggal 11 Mei 2020. Kegiatan pendahuluan meliputi: menyapa siswa, mengecek kesiapan siswa melalui grub WhatsApp, mengingatkan 3M (memakai masker, menjaga jarak, mencuci tangan). membagikan tautan google meet berdoa, menyampaikan kompetensi dasar (KD), memotivasi siswa, menyampaikan tujuan pembelajaran materi: Peluang teoritik serta perbandingan peluang empirik dan peluang teoritik; menyampaikan alat dan bahan; teknik penilaian; memberikan apersepsi dengan mengingatkan kembali siswa pada materi pertemuan sebelumnya yaitu Peluang empirik.

Pada kegiatan inti guru memberikan rangsangan dengan meminta siswa mengamati materi video Peluang teoritik, serta perbandingan peluang empirik dan peluang teoritik. Siswa mengidentifikasi masalah dengan menanyakan hal-hal yang dianggap sulit, diskusi dengan melakukan percobaan untuk mengumpulkan data, dan mengemukakan pendapat sebagai pembuktian. Guru mengajak siswa menyanyikan lagu yel-yel "Belajar Matematika" sebagai selingan supaya siswa tidak jenuh, mengarahkan dan membimbing siswa untuk menyimpulkan materi pelajaran.

Pada kegiatan penutup guru bersama siswa melakukan refleksi pembelajaran, meminta siswa untuk mengerjakan kuis, mengumumkan materi pertemuan yang akan datang yaitu penilaian harian Peluang, memberikan Penugasan 5 membuat poster untuk memerangi "Covid-19" pada google classroom dan menutup pelajaran dengan meminta siswa untuk berdoa dan mengucapkan salam.

Pada Siklus 2 pertemuan 3 dilaksanakan pada hari Selasa, tanggal 12 Mei 2020. Guru menyapa siswa, kemudian mengecek kesiapan belajar siswa melalui WhatsApp grub kelas sebagai media komunikasi dan mengingatkan 3M (memakai masker, menjaga jarak, mencuci tangan), mengajak siswa untuk joint/ gabung di google classroom. setelah siswa berhasil login meminta salah satu siswa untuk memimpin doa "supaya tetap sehat dan lancar belajarnya". Selanjutnya Guru menyampaikan tujuan pembelajaran, mmberikan motivasi supaya siswa jujur dalam mengerjakan pengisian kuesioner motivasi belajar matematika, pengisian angket pembelajaran dan penilaian harian, membagikan tautan angket pembelajaran dan tautan kuesioner motivasi belajar matematika, membagikan tautan penilaian harian Matematika kelas VIII-6, memantau jalannya penilaian harian, mengingatkan kepada 
siswa bahwa waktu tinggal lima menit lagi untuk tidak lupa submit. Pelajaran diakhiri dengan meminta siswa untuk berdoa dan mengucapkan salam.

Observasi siklus 2, aktivitas siswa yang diamati oleh guru dan kolaborator selama proses pembelajaran dengan menerapkan model pembelajaran discovery learning dan menggunakan aplikasi google suite for education pada siklus 1 terdiri dari: hadir tepat waktu/online pada saat pembelajaran jarak jauh 94\%; tepat waktu mengumpulkan tugas $92 \%$; senang memecahkan soal $97 \%$; terlibat aktif/merespon dalam proses pembelajaran jarak jauh 94\% dan menyampaikan Ide/pendapat 86\%. Hasil pengamatan melalui lembar observasi siswa tersebut menunjukkan rata-rata keaktifan siswa secara keseluruhan mencapai $92,6 \%$ telah melampaui target indikator keberhasilan penelitian ini yaitu $75 \%$. Hal ini berarti penerapan model pembelajaran discovery learning dan penggunaan aplikasi google suite for education dapat megaktifkan siswa pada proses pembelajaran jarak jauh.

Hasil pengamatan aktivitas guru yang dilakukan pada siklus 2 diperoleh dari lembar pengamatan (observasi) ketika pembelajaran dengan menerapkan model pembelajaran discovery learning dan menggunakan aplikasi google suite for education. Guru telah melaksanakan langkahlangkah pembelajaran dengan tepat, karena aspek yang di amati oleh kolaborator seluruhnya dinilai sangat baik. Hasil angket siswa juga menunjukkan bahwa proses belajar mengajar secara daring menerapkan model discovery learning dan menggunakan aplikasi google suite for education mendapat respon positif oleh siswa.

Rata-rata skor motivasi belajar matematika termasuk kategori sedang yaitu 77,72. Hal ini disebabkan guru menerapkan model pembelajaran discovery learning dan menggunakan aplikasi google suite for education pada proses pembelajaran jarak jauh pelajaran matematika materi Statistika dan Peluang dengan langkah-langkah yang benar sehingga dapat mendorong siswa meningkatkan motivasi belajar matematika dalam dirinya. Siswa yang memiliki motivasi belajar matematika kategori tinggi pada siklus 2 adalah 21 orang (58,3\%), siswa yang memiliki motivasi belajar matematika kategori sedang sebanyak 13 orang (36,1\%), namun pada siklus 2 masih ada siswa yang memiliki motivasi belajar matematika kategori rendah yaitu sebanyak 2 orang $(5,6 \%)$. Hal ini disebabkan karena anak-anak tersebut kurang terlibat aktif dalam pembelajaran jarak jauh dan hadir terlambat online pada saat pembelajaran jarak jauh.

Refleksi siklus 2 menunjukkan motivasi belajar matematika siswa mengalami peningkatan yaitu $6,2 \%$, sedangkan aktivitas siswa dalam proses pembelajaran jarak jauh mengalami peningkatan $9,2 \%$. Dari hasil yang dicapai pada siklus 2 dapat dikatakan bahwa penerapan model pembelajaran discovery learning dan penggunaan aplikasi google suite for education berhasil, untuk itu tindakan pada siklus 2 ini dapat dihentikan.

Peningkatan motivasi belajar matematika dari siklus 1 ke siklus 2 diiringi dengan meningkatnya aktivitas dalam pembelajaran seperti yang disajikan pada Tabel 1. Berdasarkan analisis Tabel 1 menemukan bahwa, proses pembelajaran jarak jauh melalui Discovery learning dengan google suite for education dalam materi peluang menunjukkan peningkatan. Peningkatan aktivitas belajar siswa dari siklus 1 ke siklus 2 meliputi: siswa lebih bersemangat mengikuti pembelajaran jarak jauh dengan hadir tepat waktu $12 \%$; mengumpulkan tugas tepat waktu $11 \%$; senang memecahkan soal/masalah $10 \%$; terlibat aktif dalam proses pembelajaran jarak jauh $2 \%$; lebih percaya diri dalam menyampaikan pendapat $11 \%$.

Tabel 1. Perbandingan Aktivitas siswa pada Siklus 1 dan Siklus 2.

\begin{tabular}{ccccc}
\hline \multirow{2}{*}{ No. } & Aspek yang dinilai & \multicolumn{2}{c}{ Persentase Keaktifan } & \multirow{2}{*}{ Peningkatan } \\
\cline { 3 - 4 } & & Siklus 1 & Siklus 2 & \\
\hline 1 & Hadir tepat waktu PJJ & $82 \%$ & $94 \%$ & $12 \%$ \\
2 & Kumpul tugas tepat waktu & $81 \%$ & $92 \%$ & $11 \%$ \\
3 & Senang memecahkan soal & $87 \%$ & $97 \%$ & $10 \%$ \\
4 & Terlibat aktif dlm PJJ & $92 \%$ & $94 \%$ & $2 \%$ \\
5 & Menyampaikan Ide/pendapat & $75 \%$ & $86 \%$ & $11 \%$ \\
\hline Rata-rata & $83,4 \%$ & $92,6 \%$ & $9,2 \%$ \\
\hline
\end{tabular}


Persentase aktivitas siswa dari siklus 1 ke siklus 2 dikarenakan setiap kekurangan yang terjadi pada siklus sebelumnya diperbaiki untuk pelaksanaan siklus berikutnya.

Motivasi belajar siswa dari siklus 1 sampai siklus 2 mengalami peningkatan. Artinya pembelajaran jarak jauh melalui Discovery learning dengan google suite for education dapat meningkatkan motivasi belajar matematika siswa. Peningkatan motivasi belajar tiap siklus dapat dilihat dari Tabel 2. ratarata skor motivasi sebesar 73,17 kategori sedang pada siklus 1 meningkat menjadi 77,72 kategori tinggi pada siklus 2. Hal ini mengalami peningkatan dari siklus pertama sebesar 4,55 (6,2\%).

Pada siklus 1 siswa yang memiliki motivasi belajar matematika kategori tinggi sebanyak 50\% sedangkan pada siklus 2 siswa yang memiliki motivasi belajar matematika kategori tinggi sebanyak $58,3 \%$ sehingga motivasi belajar matematika kategori tinggi mengalami peningkatan sebesar $8,3 \%$. Pada siklus 1 siswa yang memiliki motivasi belajar matematika kategori sedang sebanyak 33,3\%, pada siklus 2 siswa yang memiliki motivasi belajar sedang sebanyak 36,1\% sehingga motivasi belajar matematika kategori sedang mengalami peningkatan sebesar 2,8\%. Pada siklus 1 siswa yang memiliki motivasi belajar kategori rendah sebanyak $16,7 \%$, pada siklus 2 siswa yang memiliki motivasi belajar kategori rendah sebanyak 5,6\% sehingga motivasi belajar matematika kategori rendah mengalami penurunan sebesar $11,1 \%$.

Tabel 2. Perbandingan Motivasi Belajar Matematika Siswa pada Siklus 1 dan Siklus 2

\begin{tabular}{|c|c|c|c|c|c|c|c|}
\hline \multirow{2}{*}{ No. } & \multirow{2}{*}{ Uraian } & \multicolumn{3}{|c|}{ Siklus 1} & \multicolumn{3}{|c|}{ Siklus 2} \\
\hline & & Rendah & Sedang & Tinggi & Rendah & Sedang & Tinggi \\
\hline \multirow[t]{2}{*}{1} & Banyak siswa yang memiliki motivasi belajar & 6 & 12 & 18 & 2 & 13 & 21 \\
\hline & Matematika & $(16,7 \%)$ & $(33,3 \%)$ & $(50 \%)$ & $(5,6 \%)$ & $(36,1 \%)$ & $(58,3 \%)$ \\
\hline \multirow[t]{10}{*}{2} & Indikator Motivasi Belajar Matematika & & & & & & \\
\hline & Tekun dalam menghadapi tugas & $13.9 \%$ & $30.6 \%$ & $55.6 \%$ & $2.8 \%$ & $47.2 \%$ & $50.0 \%$ \\
\hline & Ulet dalam menghadapi Kesulitan & $13.9 \%$ & $27.8 \%$ & $58.3 \%$ & $8.3 \%$ & $22.2 \%$ & $69.4 \%$ \\
\hline & Menunjukkan minat & $13.9 \%$ & $38.9 \%$ & $47.2 \%$ & $5.6 \%$ & $50.0 \%$ & $44.4 \%$ \\
\hline & Senang bekerja mandiri & $16.7 \%$ & $27.8 \%$ & $55.6 \%$ & $5.6 \%$ & $41.7 \%$ & $52.8 \%$ \\
\hline & Cepat bosan pada tugas-tugas rutin & $16.7 \%$ & $33.3 \%$ & $50.0 \%$ & $5.6 \%$ & $38.9 \%$ & $55.6 \%$ \\
\hline & Dapat mempertahankan Pendapatnya & $22.2 \%$ & $52.8 \%$ & $25.0 \%$ & $19.4 \%$ & $52.8 \%$ & $27.8 \%$ \\
\hline & Tidak mudah melepas hal yang diyakini itu & $27.8 \%$ & $36.1 \%$ & $36.1 \%$ & $11.1 \%$ & $44.4 \%$ & $44.4 \%$ \\
\hline & Senang mencari dan memecahkan masalah/soal- & $19.4 \%$ & $55.6 \%$ & $25.0 \%$ & $11.1 \%$ & $58.3 \%$ & $30.6 \%$ \\
\hline & Uraian & & Siklus 1 & & & Siklus 2 & \\
\hline \multirow{3}{*}{ 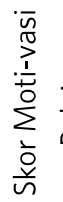 } & Skor Tertinggi & & 98 & & & 100 & \\
\hline & $\frac{\bar{v}}{\overline{0}}$ Skor Terendah & & 30 & & & 49 & \\
\hline & Rata-rata Skor & & 73.17 & & & 77.72 & \\
\hline
\end{tabular}

Peningkatan motivasi belajar matematika meliputi: tekun dalam menghadapi tugas; ulet dalam menghadapi kesulitan, menunjukkan minat, senang bekerja mandiri, cepat bosan pada tugas rutin, dapat mempertahankan pendapat, tidak mudah melepas hal yang diyakini, senang mencari dan memecahkan masalah.

Motivasi belajar matematika dan keaktifan siswa menjadi lebih baik, dikarenakan siswa mulai terbiasa menggunakan aplikasi google suite for education selama proses pembelajaran jarak jauh. Siswa merasa tertarik dengan model pembelajaran discovery learning yang mengajak siswa belajar bereksperimen dan memecahkan masalah yang menantang. Hal ini sesuai dengan peran motivasi mendorong siswa ingin melakukan kegiatan belajar. Motivasi merujuk kepada seluruh proses gerakan, termasuk situasi yang mendorong, dorongan yang timbul dari dalam diri individu, perilaku yang ditimbulkan oleh situasi tersebut dan tujuan atau akhir daripada tindakan atau perbuatan (Sarwono 2012). 
Penggunaan model pembelajaran discovery learning dalam pembelajaran sangat penting karena dapat meningkatkan keaftian, minat, dan kesadaran/ motivasi untuk belajar. Oleh karena itu dalam pembelajaran hendaknya guru dapat berinovasi untuk memotivasi dan meningkatkan kualitas pembelajaran dengan model yang bervariasi dan media yang sesuai, sehingga hasil belajar dapat maksimal (Firdayati 2020).

Penelitian relevan menyatakan bahwa pembelajaran matematika berbasis goolge suite for education menarik dan bervariasi, sehingga siswa dapat memahami materi dan menyelesaikan tugas. Siswa lebih mengerti menggunakan aplikasi dan fasilitas dari google dengan baik dan benar, serta mudah dalam berkolaborasi dan berkomunikasi (Talib, Suaedi, and Ilyas 2021).

Penelitian lainnya menyatakan pembelajaran jarak jauh pada situasi pandemi Covid-19 melalui google suite for education yang memiliki bermacam-macam fitur seperti google classroom dan google meet memudahkan guru dalam melaksanakan pembelajaran dan siswa menjadi lebih tertarik dan antusias (Nirmala, Triaswati, and Rahmawan 2020).

Penelitian yang menerapkan google suite for education dalam pembelajaran jarak jauh pelajaran matematika di SMP menunjukkan siswa terlibat aktif dalam pembelajaran, aktivitas siswa melebihi target $70 \%$, ketuntasan belajar dan rata-rata nilai matematika sangat tinggi (Purnamasari and Kamal 2021).

Beberapa penelitian yang sejalan dengan penelitian ini yaitu: Hasibuan, dkk (Hasibuan, Rambe, and Saleh 2021) yang menunjukkan penerapan model pembelajaran discovery learning pada materi bangun ruang sisi datar dapat meningkatkan motivasi dan hasil belajar matematika; Khansa, dkk (2018) menemukan bahwa penerapan model pembelajaran discovery learning dengan strategi ARIAS pada materi relasi dan fungsi dapat meningkatkan motivasi dan pemahaman konsep siswa. Hasil temuan Firdayati (Firdayati 2020) menyatakan bahwa pembelajaran melalui discovery learning dengan geogebra pada materi transformasi dapat meningkatkan motivasi belajar siswa, sehingga aktivitas belajar siswa meningkat.

Berdasarkan analisis data di atas maka dapat disimpulkan bahwa melalui discovery learning dengan aplikasi google suite for education dapat meningkatkan motivasi belajar matematika siswa kelas VIII-6 di SMP Negeri 109 Jakarta semester genap tahun pelajaran 2019-2020.

\section{SIMPULAN DAN SARAN}

Simpulan penelitian ini adalah Pembelajaran discovery learning dengan aplikasi google suite for education dapat meningkatkan motivasi belajar matematika siswa. Peningkatan motivasi belajar matematika meliputi: tekun dalam menghadapi tugas, ulet dalam menghadapi kesulitan, menunjukkan minat, senang bekerja mandiri, cepat bosan pada tugas rutin, dapat mempertahankan pendapat, tidak mudah melepas hal yang diyakini, senang mencari dan memecahkan masalah.

Aktivitas belajar siswa meningkat, melalui pembelajaran discovery learning dengan aplikasi google suite for education siswa lebih bersemangat mengikuti pembelajaran jarak jauh dengan hadir tepat waktu; disiplin dalam mengumpulkan tugas; senang memecahkan masalah; terlibat aktif dalam proses pembelajaran jarak jauh; lebih percaya diri dalam menyampaikan pendapat; dan materi pelajaran mudah dipahami oleh siswa.

Penelitan ini memberikan rekomendasi pentingnya mengajar dengan menerapkan pembelajaran discovery learning dengan aplikasi google suite for education pada pembelajaran jarak jauh sesuai dengan kebutuhan belajar peserta didik, agar materi pembelajaran mudah dipahami siswa sehingga pembelajaran yang aktif, kreatif, efektif dan menyenangkan di dalam kelas dapat tercapai. Sekolah sebaiknya memberikan kesempatan kepada guru, untuk mengembangkan kompetensi digital abad 21 dalam pembelajaran matematika dan mendorong guru melakukan penelitian tentang inovasi pembelajaran matematika.

\section{PUSTAKA ACUAN}

Fathur, R. 2018. "Apa Itu Google Suite (G-SUITE) For Education ? Bagaimana Cara Registrasi Dan Upgradenya? Serta Perpanjangan Trial." Fathur.Web.Id/. 2018.

Firdayati, Lilik. 2020. "Peningkatan Motivasi Belajar Siswa Melalui Discovery Learning Dengan Geogebra Pada Materi Transformasi." AKSIOMA: Jurnal Program Studi Pendidikan Matematika 9, no. 3: 833-41. 
Google Edu. 2020. “Product G-Suite for Education.” Google Inc. 2020.

Hasibuan, Eka Khairani, Nur Atikah Rambe, and Syarbaini Saleh. 2021. "Penerapan Model Pembelajaran Discovery Learning Untuk Meningkatkan Motivasi Belajar Dan Hasil Belajar Matematika Siswa Kelas VIII MTS." AXIOM: Jurnal Pendidikan Dan Matematika 10, no. 1: 61-67.

Khansa, Shabrina Lini, Ikrar Pramudya, and Yemi Kuswardi. 2018. "Penerapan Model Pembelajaran Discovery Learning Dengan Strategi Arias Untuk Meningkatkan Pemahaman Konsep Dan Motivasi Belajar Pada Materi Relasi Dan Fungsi." Jurnal Pendidikan Matematika Dan Matematika SOLUSI 2, no. 4: 259-72.

Nirmala, Ahmad Aldi, Ervi Triaswati, and Auliya Fajrin Rahmawan. 2020. "Implementation of the GSE (Google Suite Education) Program at SD Muhammadiyah 09 Plus in the Covid-19 Pandemic Era." Omega 6, no. 2.

Purnamasari, Evi Sugiana, and Muhammad Choirul Kamal. 2021. "Inovasi Learning Management System (LMS) Menggunakan Google Suite For Education (GSE) Dalam Pembelajaran Jarak Jauh Bidang Studi Matematika Siswa Kelas IX Di SMP Negeri 6 Pekalongan." Delta: Jurnal Ilmiah Pendidikan Matematika 9, no. 2.

Samin, M. 2020. "Strategi Belajardari Rumah Dengan Atau Tanpa Internet Di Tahun Ajaran Baru." Kompas Online, May 2020.

Sardiman, A.M. 2018. Interaksi \& Motivasi Belajar Mengajar. Depok: Rajawali Press.

Sarwono, Sarlito W. 2012. "Pengantar Psikologi Umum." Jakarta: Rajawali Press.

Suhardjono. 2009. Penelitian Tindakan Kelas, Penelitian Tindakan Sekolah. Malang: Cakrawala Indonesia.

Syah, Muhibbin. 2010. Psikologi Pendidikan Dengan Pendekatan Baru. Bandung: PT Remaja Rosdakarya.

Talib, Abi, Suaedi Suaedi, and Muhammad Ilyas. 2021. "Pembelajaran Matematika Berbasis Google Suite For Education Untuk Meningkatkan Kecakapan Kolaboratif Siswa." Teorema: Teori Dan Riset Matematika 6, no. 1: 34-47.

Wahyuningsih, Dian, and Rakhmat Makmur. 2017. E-Learning Teori Dan Aplikasi. Bandung: Informatika Bandung. Vol. 4. 